\title{
Copper Dissoliution in Concentrated Sulfuric Acid
}

\author{
A. Sulcius* , E. Griskonis, N. Zmuidzinaviciene \\ Kaunas University of Technology, Lithuania \\ *Corresponding author: algirdas.sulcius@ktu.lt \\ Received March 08, 2019; Revised May 04, 2019; Accepted May 29, 2019
}

\begin{abstract}
When redox reactions are studied in the chemistry course, focus is limited to the use of a series of metal activity, electron or electron-ion balance method, and writing of the reaction equations. Students find the redox reactions that occur during the dissolution of metals in acids difficult. Motivated students should be able to solve four problems while studying redox reactions: 1) indicate oxidizing agent and reducing agent; 2) write correct products forming and balance the redox reaction; 3) calculate the electromotive force $\mathrm{E}^{0}$ of the redox reaction; 4) indicate the thermodynamic possibility of the occurrence of redox reaction by calculating Gibbs energy $\Delta \mathrm{G}^{0}$. The proposed improved methodology for studying the reactions of dissolution of metals in acids allows students to systematize and expand knowledge about redox reactions in inorganic chemistry. To improve the assimilation of knowledge about the dissolution of copper in sulfuric acid, mnemonic scheme has been proposed that makes it possible to understand better composition of the products. Copper reacted with concentrated sulfuric acid only when heated and precipitation of black deposit was observed. The amount of black deposit in the acid and on the surface of copper depended on the method and intensity of heating: heating with interruptions or intensive continuous heating. It has been determined, that during copper dissolution in concentrated $96 \%$ sulfuric acid two reactions take place (the main and the parallel) and precipitation of black deposit, consisting mainly of $\mathrm{Cu}_{2} \mathrm{~S}$ and a small amount of $\mathrm{Cu}_{2} \mathrm{O}$, is observed.
\end{abstract}

Keywords: high school/introductory chemistry, inorganic chemistry, mnemonics/rote learning, metals, oxidation/reduction, reactions

Cite This Article: A. Sulcius, E. Griskonis, and N. Zmuidzinaviciene, "Copper Dissoliution in Concentrated Sulfuric Acid." World Journal of Chemical Education, vol. 7, no. 3 (2019): 196-202. doi: 10.12691/wjce-7-3-2.

\section{Introduction}

Since mineral or inorganic acids (sulfuric $\mathrm{H}_{2} \mathrm{SO}_{4}$ and nitric $\mathrm{HNO}_{3}$ ) are the most frequently used chemicals in research and industry, one of the most important issues is the interaction of metals with solutions of strong acids. Students have serious difficulties when studying different chemistry sections, especially the one related to redox reactions. Students find the redox reactions that occur during the dissolution of metals in sulfuric acid, and especially in nitric acid, difficult. In the 19th century, Mendeleev wrote, "No equation expresses everything that, in fact, takes place under the action of metals on nitric acid, since always several oxides of nitrogen are formed together or sequentially one after another, depending on the acid strength and temperature." [1]. It is known, that during dissolution of metals in nitric acid, different gaseous products such as $\mathrm{N}_{2} \mathrm{O}, \mathrm{N}_{2}, \mathrm{NO}, \mathrm{NO}_{2}, \mathrm{NH}_{3}$ [2], and $\mathrm{H}_{2}[3]$ are formed. It has been also proven that dissolution rate of copper $\mathrm{Cu}$ in nitric acid is not controlled entirely by rate of chemical reaction and that it is affected by degree of agitation [4]. Recently, using Fourier transform infrared spectroscopy it has been demonstrated that $\mathrm{NO}_{2}, \mathrm{~N}_{2} \mathrm{O}_{4}$ and $\mathrm{NO}$ are the dominant gas phase products of the copper reactions in concentrated and dilute nitric acid, respectively [5].
Many problems involving writing redox reaction equations are solved by memorizing responses or reaction algorithms. However, a person cannot remember everything and does not need to. In order to facilitate and improve learning, different methods such as algorithms $[6,7]$ and mnemonic schemes $[8,9]$ are used. It has been found that visual algorithmic or mnemonic schemes used in studying facilitate the training of teachers and increase the uptake of knowledge and skills of the students.

Chemistry is an experimental science by its nature, therefore in order to consolidate theoretical knowledge students should carry out experimental work in laboratories. Although the use of laboratory works is a rare phenomenon [10], it is known that inquiry based education (IBE) significantly increases the uptake of knowledge and skills [11]. However, Fortus et al. [12] have found that majority of students follow only the instructions for laboratory experiments, what does not encourage students' creativity and critical thinking $[13,14]$.

Copper and its alloys, as well as zinc and it alloys due its protection from corrosion, are the most applicable materials used in industry due to their high electrical conductivity, mechanical workability, relatively noble properties, and good availability. There are many experiments for zinc and copper reactions in dilute sulfuric acid [15-19]. In the textbooks, dissolution of 
copper in concentrated sulfuric acid is expressed by a typical reaction equation $[20,21]$ :

$$
\begin{aligned}
& \mathrm{Cu}(\mathrm{s})+2 \mathrm{H}_{2} \mathrm{SO}_{4}(\mathrm{l}) \\
& \stackrel{\text { conc., } \Delta}{\longrightarrow} \mathrm{CuSO}_{4}(\mathrm{aq})+\mathrm{SO}_{2}(\mathrm{~g})+2 \mathrm{H}_{2} \mathrm{O}(1)
\end{aligned}
$$

While reviewing scientific literature, it has been found that besides reaction 1 a number of other parallel reactions take place when copper dissolves in concentrated sulfuric acid. The copper surface becomes passive because $\mathrm{Cu}_{2} \mathrm{O}$, $\mathrm{CuO}, \mathrm{Cu}_{2} \mathrm{~S}, \mathrm{CuS}$ and $\mathrm{CuSO}_{4}$ deposits form on the copper metal surface:

$$
\begin{aligned}
& 4 \mathrm{Cu}(\mathrm{s})+4 \mathrm{H}_{2} \mathrm{SO}_{4}(1) \\
& \stackrel{\text { conc. }}{\longrightarrow} 3 \mathrm{CuSO}_{4}(\mathrm{aq})+\mathrm{CuS}(\mathrm{s})+4 \mathrm{H}_{2} \mathrm{O}(1) \\
& 5 \mathrm{Cu}(\mathrm{s})+4 \mathrm{H}_{2} \mathrm{SO}_{4}(1) \\
& \stackrel{\text { conc. }}{\longrightarrow} 3 \mathrm{CuSO}_{4}(\mathrm{aq})+\mathrm{Cu}_{2} \mathrm{~S}(\mathrm{~s})+4 \mathrm{H}_{2} \mathrm{O}(1) \\
& \mathrm{Cu}(\mathrm{s})+2 \mathrm{H}_{2} \mathrm{SO}_{4}(1) \\
& \stackrel{92 \%}{\longrightarrow} \mathrm{CuSO}_{4}(\mathrm{~s})+\mathrm{SO}_{2}(\mathrm{~g})+2 \mathrm{H}_{2} \mathrm{O}(\mathrm{l}) \\
& \mathrm{Cu}(\mathrm{s})+\mathrm{H}_{2} \mathrm{SO}_{4}(1) \\
& \stackrel{\text { conc.,cold }}{\longrightarrow} \mathrm{CuO}(\mathrm{s})+\mathrm{SO}_{2}(\mathrm{~g})+\mathrm{H}_{2} \mathrm{O}(\mathrm{l}) \\
& 2 \mathrm{Cu}(\mathrm{s})+2 \mathrm{H}_{2} \mathrm{SO}_{4}(1) \\
& \text { anhydrous, } 200^{\circ} \mathrm{C} \longrightarrow \mathrm{Cu}_{2} \mathrm{SO}_{4}(\mathrm{~s})+\mathrm{SO}_{2}(\mathrm{~g})+2 \mathrm{H}_{2} \mathrm{O}(\mathrm{l}) \\
& 2 \mathrm{Cu}(\mathrm{s})+\mathrm{H}_{2} \mathrm{SO}_{4}(1) \\
& \stackrel{\text { conc., cold }}{\longrightarrow} \mathrm{Cu}_{2} \mathrm{O}(\mathrm{s})+\mathrm{SO}_{2}(\mathrm{~g})+\mathrm{H}_{2} \mathrm{O}(\mathrm{l})
\end{aligned}
$$

It has been noted that along with reaction 1 , the formation of black $\mathrm{Cu}_{2} \mathrm{~S}$ deposit (reaction 3) occurs. The rate of this reaction is maximal at $100^{\circ} \mathrm{C}$. While increasing temperature, the process rate decreases, and stops above $270{ }^{\circ} \mathrm{C}$ [28]. It has been stated that reaction 4 takes place in $92-96 \%$ sulfuric acid and the light grey crystals of $\mathrm{CuSO}_{4}(\mathrm{~s})$ are formed. When concentration of sulfuric acid is higher than $96 \%$, a large amount of black $\mathrm{CuO}(\mathrm{s})$ deposit (reaction 5) along with the light grey crystals of $\mathrm{CuSO}_{4}(\mathrm{~s})$ [28] are formed. The copper ionization mechanism during anodic dissolution in concentrated sulfuric acid is represented in the scheme [29]:

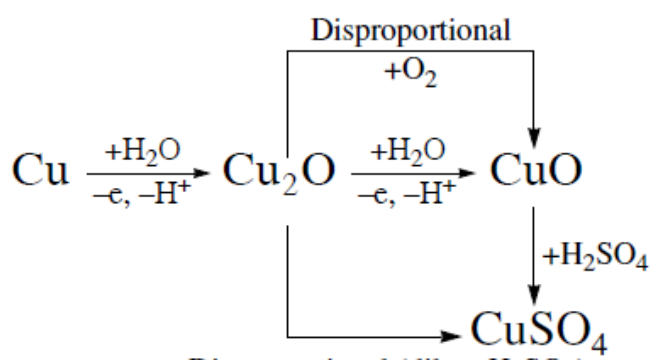

Disproportional (dilute $\mathrm{H}_{2} \mathrm{SO}_{4}$ )

The goal of our research is to study thoroughly the copper dissolution reaction in concentrated sulfuric acid and provide students with auxiliary material for a deeper understanding of redox reactions occurring when metals dissolve in strong acids.

\section{EXPERIMENTAL}

In the experiments, sulphuric acid $\left(\mathrm{H}_{2} \mathrm{SO}_{4}\right.$, Eurochemicals, 96 wt. \%, analytic grade), nitric acid $\left(\mathrm{HNO}_{3}\right.$, Penta, 65 wt. \%, analytic grade), Prussian blue $\left(\mathrm{K}_{4}\left[\mathrm{Fe}(\mathrm{CN})_{6}\right]\right.$, Sigma-Aldrich, 99 wt. \% purity), barium chloride $\left(\mathrm{BaCl}_{2}\right.$, Sigma-Aldrich, 99 wt. \% purity) and copper(II) oxide powder (CuO, Reachim, 99 wt. \% purity) were used. Double distilled water was used for washing of deposits and diluting of solutions.

Copper plate and wire produced from certified oxygenfree high-conductivity copper (UNS C10100, purity > 99 wt. \%) were used.

The structure of deposits was investigated by XRD using a Bruker diffractometer (model D8 Advance), and diffraction patterns were identified using Bruker AXS software (program EVA) and PDF-2 database. The morphology and detailed elemental analysis of the surface of deposits were investigated using a scanning electron microscope Hitachi S-3400N (SEM) with an energy dispersive X-ray (EDX) spectral analyzer Bruker Quad 5040 EDS.

\section{HAZARDS}

Contact of $\mathrm{H}_{2} \mathrm{SO}_{4}$ and $\mathrm{HNO}_{3}$ with your skin or your eyes should be avoided! During all experiments with these acids protective equipment (lab coat, rubber gloves, eyeglasses, fume hood) should be used! Students should work under close supervision when handling strong acids. In the case of contact with these acids, the contact area should be rinsed with plenty of water and medical care should be sought. Since barium chloride $\mathrm{BaCl}_{2}$ is highly toxic and harmful, sodium sulphate $\mathrm{Na}_{2} \mathrm{SO}_{4}$ could be used as antidotes because it forms barium sulfate $\mathrm{BaSO}_{4}$, which is relatively non-toxic due to its very low solubility.

The chemicals should be disposed of according to state and local environmental regulations. Solutions should be collected in separate waste containers, disposed of according to EPA standards.

\section{Results and Discussion}

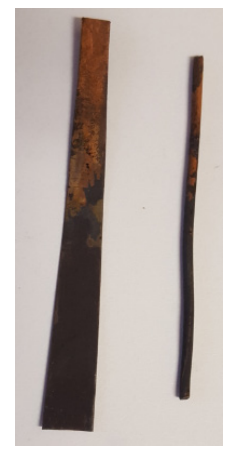

Figure 1. Black deposit on the surface of copper, which was formed during copper dissolution in concentrated sulfuric acid

Copper reacted with concentrated sulfuric acid only when heated and precipitation of black deposit was observed (Figure 1). The amount of black deposit in the acid and on the surface of copper depended on the method and intensity of heating: heating with interruptions or intensive continuous heating. When heating sulfuric acid with interruptions, a large amount of black deposit was formed in the acid and on the surface of copper. After precipitation of black deposit, the acid solution was 
colorless and transparent, anhydrous copper sulphate is formed because concentrated sulfuric acid is the dryer [30]. After dilution colourless and transparent solution became blue forming $\mathrm{CuSO}_{4} \cdot 5 \mathrm{H}_{2} \mathrm{O}$. In the case of intensive continuous heating, black deposit was formed initially in the acid and on the copper surface, the amount of which in the acid and on the surface of copper decreased with further heating, until it disappeared in the acid and only small amount remained on the copper surface. Then solution turned blue. To avoid the influence of ions $\mathrm{SO}_{4}{ }^{2-}$, the black deposit on the surface of the copper plate or wire was washed thoroughly with distilled water, kept in distilled water for 6 hours, dried, and analyzed by SEM and XRD methods (Figure 2 and Figure 3).

The results XRD have shown that mainly $\mathrm{Cu}_{2} \mathrm{~S}$ prevail in deposit as well as small amount of $\mathrm{Cu}_{2} \mathrm{O}$ (Figure 4). The results of EDX have also confirmed that the amount of sulfur is 3.65 times higher than that of oxygen (20.62 and 5.65. at. \%, respectively). Low $\mathrm{O}$ concentration in deposit may be due to the fact that most of the resulting $\mathrm{Cu}_{2} \mathrm{O}$ dissolves when the concentrated sulfuric acid is heated:

$$
\begin{aligned}
& \mathrm{Cu}_{2} \mathrm{O}(\mathrm{s})+3 \mathrm{H}_{2} \mathrm{SO}_{4}(\mathrm{l}) \\
& \stackrel{96 \%, \Delta}{\longrightarrow} 2 \mathrm{CuSO}_{4}(\mathrm{aq})+\mathrm{SO}_{2}(\mathrm{~g})+3 \mathrm{H}_{2} \mathrm{O}(1)
\end{aligned}
$$

Based on the experimental data, the copper dissolution reaction in concentrated sulfuric acid could be represented by the scheme:

a

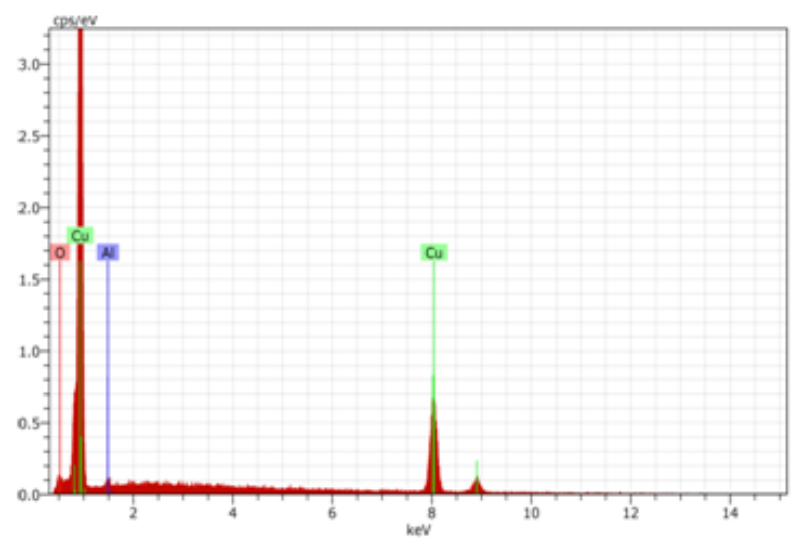

\begin{tabular}{|c|c|c|}
\hline Element & C norm [wt. \%] & $\mathrm{C}$ atom.[at.\%] \\
\hline Oxygen & 0.63 & 2.41 \\
\hline Copper & 98.49 & 95.56 \\
\hline Aluminium & 0.89 & 2.03 \\
\hline Total & 100.0 & 100.0 \\
\hline
\end{tabular}

b

$$
\mathrm{Cu} \stackrel{e^{-}}{\longrightarrow} \mathrm{Cu}^{+} \stackrel{e^{-}}{\longrightarrow} \mathrm{Cu}^{2+}
$$

When redox reactions are studied in the chemistry course, focus is limited to the use of a series of metal activity, electron or electron-ion balance method, and writing of the reaction equations. Students find the redox reactions that occur during the dissolution of metals in acids difficult. Motivated students should be able to solve four problems while studying redox reactions:

1) indicate oxidizing agent and reducing agent;

2) write correct products forming and balance the redox reaction;

3) calculate the electromotive force $E^{0}$ of the redox reaction;

4) indicate the thermodynamic possibility of the occurrence of redox reaction by calculating Gibbs energy $\Delta \mathrm{G}^{0}$.

As mentioned above, students find the redox reactions that occur during the dissolution of metals in acids difficult. Already the first two problems cause great difficulty for students. It is believed that it is more correct to indicate at least the formulas of the resulting products. This could be done by two ways: by using formulas of the resulting products presented in the table or using mnemonic schemes. In order to help students write and determine the probability of reactions of metal dissolution in concentrated sulfuric acid, the authors offer a mnemonic scheme (Figure 5) for students, where products are listed in a clockwise direction toward increasing oxidation number of sulfur.

c

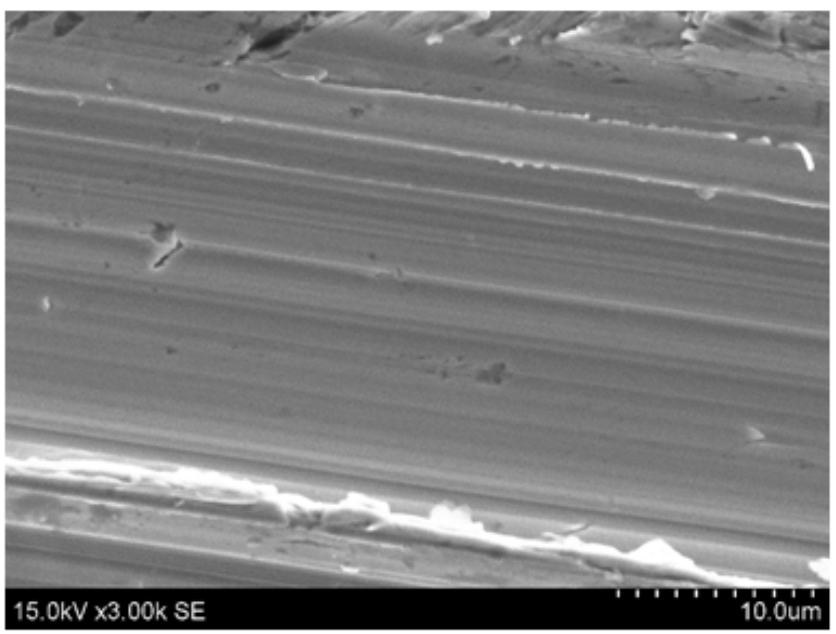

Figure 2. EDX spectra (a), elemental composition (b) and SEM image (c) of mechanically scrubbed copper surface 
a

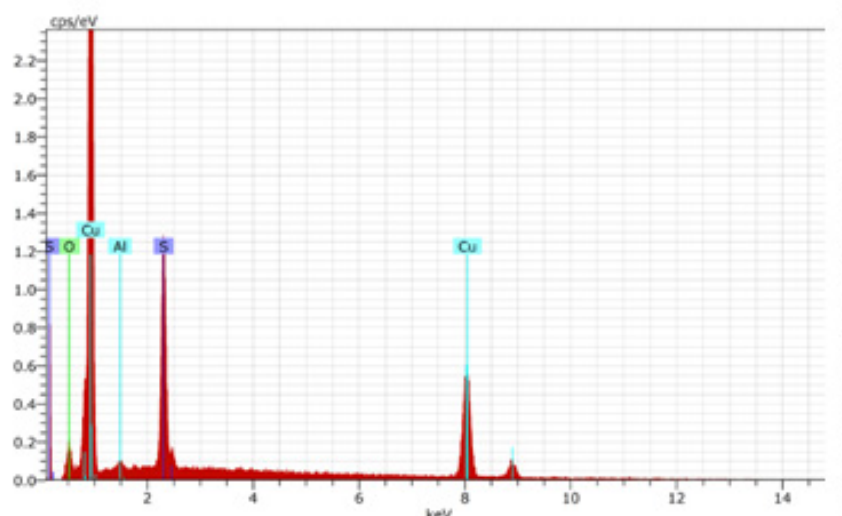

b

\begin{tabular}{|c|c|c|}
\hline Element & C norm [wt. \%] & $\mathrm{C}$ atom.[at.\%] \\
\hline Oxygen & 1.68 & 5.65 \\
\hline Sulfur & 12.27 & 20.62 \\
\hline Copper & 85.41 & 72.45 \\
\hline Aluminium & 0.64 & 1.28 \\
\hline Total & 100.0 & 100.0 \\
\hline
\end{tabular}

Figure 3. EDX spectra (a), elemental composition (b), SEM image (c) and elemental mapping (d) of deposits on the surface of copper, exposed in concentrated $\mathrm{H}_{2} \mathrm{SO}_{4}$

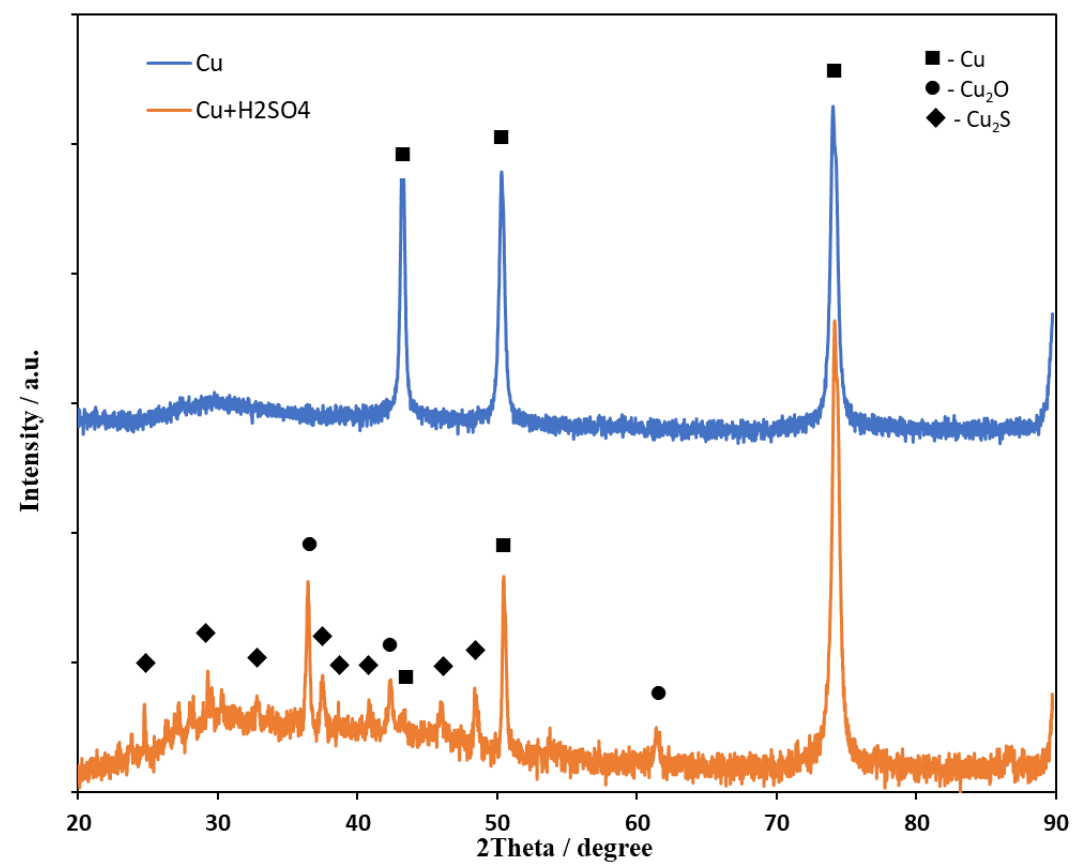

Figure 4. X-ray diffraction patterns of copper and deposit, formed on the surface of copper, exposed in concentrated $\mathrm{H}_{2} \mathrm{SO}_{4}$

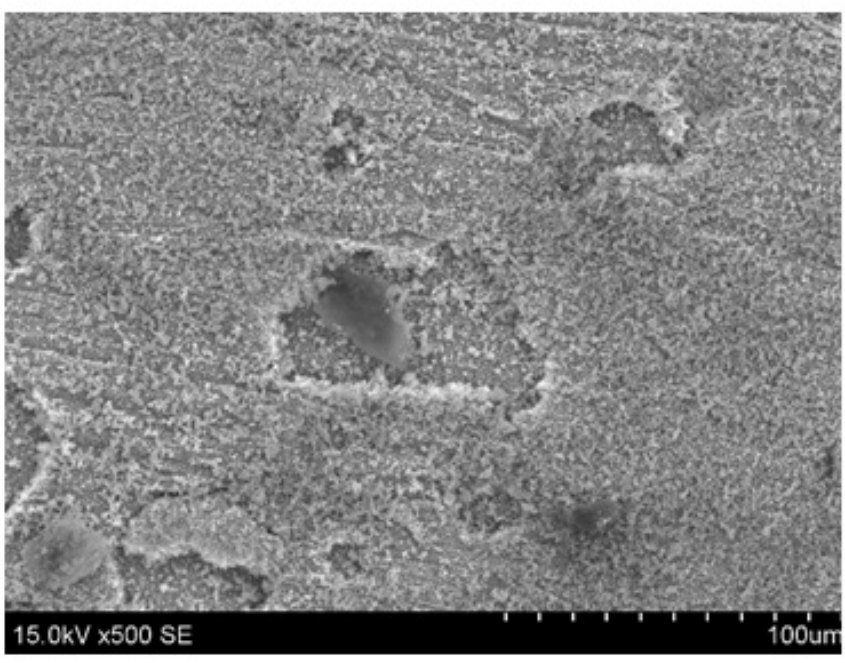

d

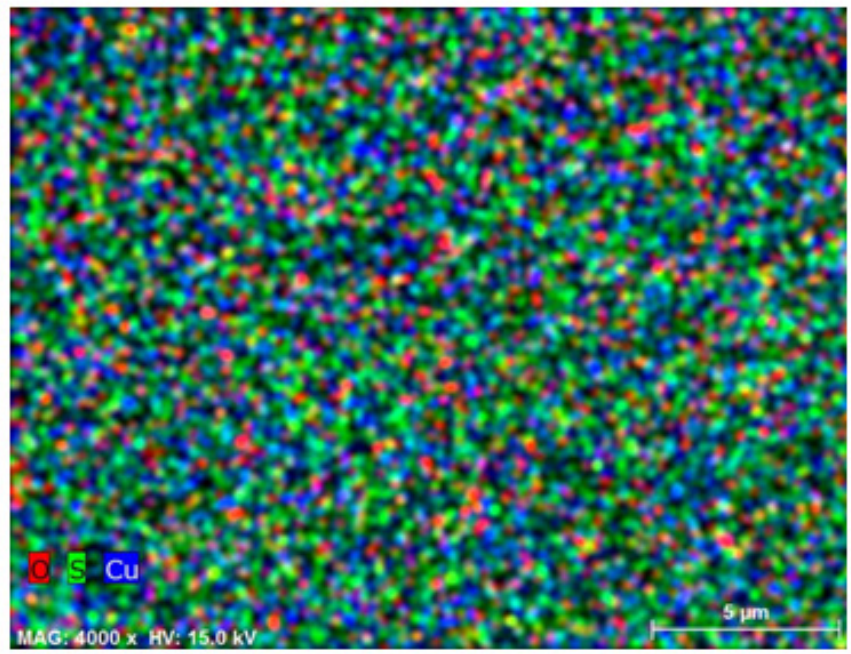




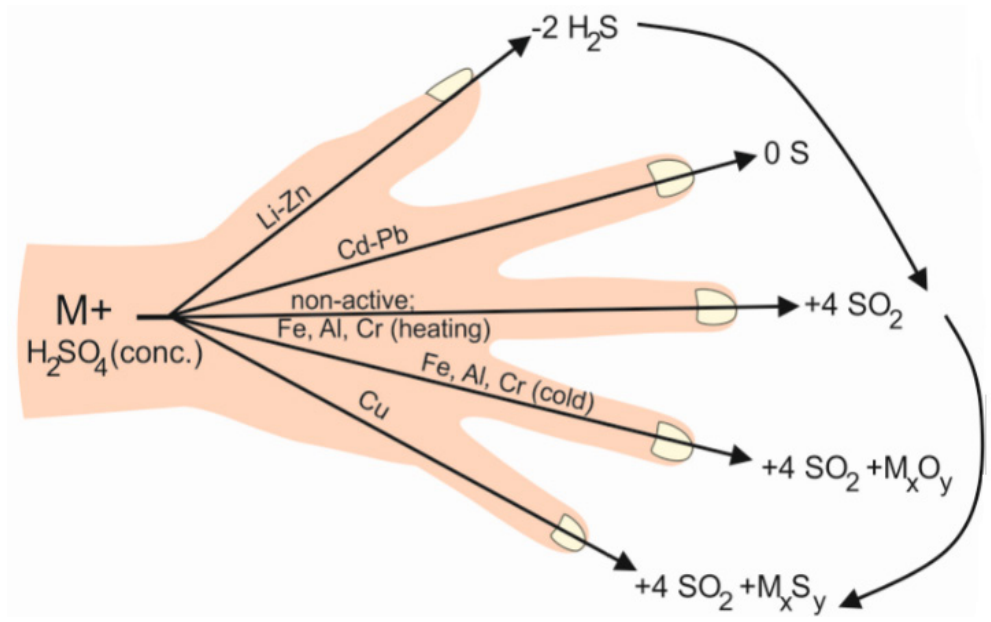

Figure 5. Suggested mnemonic scheme indicates the reduction products in concentrated sulfuric acid

As shown above, when copper dissolves in concentrated $96 \%$ sulfuric acid, three reactions could take place: the main one and two side or parallel reactions. Therefore, when students are solving the problem of redox reaction, which takes place during copper dissolution in concentrated sulfuric acid, they could be offered to use Table 1.

Table 1. Unbalanced reactions, which take place during $\mathrm{Cu}$ dissolution reaction in concentrated $96 \%$ sulfuric acid

\begin{tabular}{|c|c|}
\hline The main reaction & 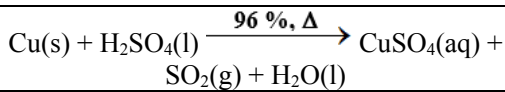 \\
\hline $\begin{array}{l}\text { Side or parallel } \\
\text { reactions }\end{array}$ & 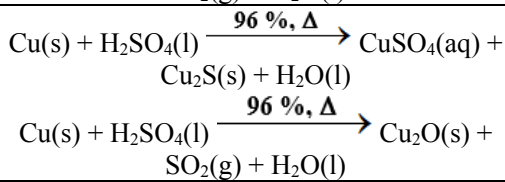 \\
\hline
\end{tabular}

For detection of all possible reaction products $\left(\mathrm{Cu}_{\mathrm{x}} \mathrm{S}\right.$, $\mathrm{Cu}_{\mathrm{x}} \mathrm{O}, \mathrm{Cu}^{2+}$ and $\mathrm{SO}_{4}{ }^{2-}$ ions, $\mathrm{SO}_{2}$ gas) simple chemical analyses were used, which was described by students in detail (see visual materials of students experiments in Supplementary material).

\section{Conclusion}

As a long-time experience of the work at the university has shown, students do not always notice various reaction features during chemical experiments. This study aims at teaching to observe the products of copper dissolution reaction in concentrated sulfuric acid. It has been determined, that during copper dissolution in concentrated $96 \%$ sulfuric acid two reactions take place (the main and the parallel) and precipitation of black deposit, consisting mainly of $\mathrm{Cu}_{2} \mathrm{~S}$ and a small amount of $\mathrm{Cu}_{2} \mathrm{O}$, is observed.

To improve the assimilation of knowledge about the dissolution of copper in sulfuric acid, mnemonic scheme has been proposed that makes it possible to understand better composition of the products.

\section{References}

[1] Mendeleev, D. I. Collected Works. Volume IX. Gunpowder. L.- M.: Publishing House of the Academy of Sciences of the USSR, 1954.
[2] Tillu, M. M. The action of nitric acid on metals. J. Chem. Educ. 1953, 30(6), 290.

[3] Pannu, S. S. Nitric acid. J. Chem. Educ. 1984, 61(2), 174-176.

[4] Jonson, R. L.; Hobson, R.; Weber, J. H. Continuous dissolution of copper by $\mathrm{HNO}_{3}$. J. Chem. Educ. 1968, 50(8), 1194.

[5] Sytsma, T. M.; Li, A.; Ganske, J. A. Nitric Acid Acts Upon Copper: Gas Phase Product Analysis of a Historic Reaction Using Fourier Transform Infrared Spectroscopy. The Chemical Educator. 2018, 23, 58-63.

[6] Mossotti, V. G. A Simplified algorithm for Temperature Conversions. J. Chem. Edu. 2003, 80(12), 1380.

[7] Orsini, G. Exploring Do-It-Yourself Approaches in Computational Quantum Chemistry: The Pedagogical Benefits of the Classical Boys algorithm. J. Chem. Edu. 2015, 92(11), 1853-1859.

[8] Goodwin, A. The use of various schemas to assist science teaching and learning. J. Chem. Edu. 2000, 1(1), 43-47.

[9] Kurushkin, M. Writing Reactions of Metals with Nitric Acid: A Mnemonic Device for Introductory Chemistry Students. J. Chem. Edu. 2015, 92(6), 1125-1126.

[10] Bybee, R.; McCrae, B.; Laurie, R. PISA 2006: An Assessment of Scientific Literacy. J. Res. Sci. Teach. 2009, 46(8), 865-883.

[11] Rocard, M.; Csermely, P.; Jorde, D.; Lenzen, D.; WalbergHenriksson, H.; Hemmo, V. Science Education Now: A Renewed Pedagogy for thee Future of Europe; European Commission: Brusel, 2007; p 28.

[12] Fortus, D.; Dershimer, R. C.; Krajcik, J.; Marx, R. W.; MamlokNaaman, R. Design-Based Science and Student Learning. J. Res. Sci. Teach. 2004, 41, 1081-1110.

[13] Laredo, T. Changing the First-Year Chemistry Laboratory Manual To Implement a Problem-Based Approach That Improves Student Engagement. J. Chem. Educ. 2013, 90(9), 1151-1154.

[14] DeWit, D. G. Predicting Inorganic Reaction Products: A Critical Thinking Exercise in General Chemistry. J. Chem. Educ. 2006, 83(11), 1625-1628.

[15] Eminah, J. A. Reaction between zinc and concentrated sulfuric acid to produce hydrogen sulfide. School Science Review. 2009, 91(334), 20-22.

[16] Yang, S. P. How many atomic layers of zinc are in a galvanized iron coating? An experiment for general chemistry laboratory. $J$. Chem. Educ. 2007, 84(11), 1792-1794.

[17] Rusek, M.; Benes, P.; Carroll, J. Unexpected discovery: a guidedinquiry experiment on the reaction kinetics of zinc with sulfuric acid. J. Chem. Educ. 2018, 95(6), 1018-1021.

[18] Miecinskas P. Copper dissolution rate as a function of the corroding-surface tilt. Russian Journal of Electrochemistry. 2005, 41(7), 731-735.

[19] Valsyunas, I.; Mechinskas, P.; Yasulaitene, V.; Leinartas, K. Initial stages of the copper corrosion in sulfate-containing solutions. Protection of Metals. 2002, 38(1), 71-77.

[20] Housecrof, C.E.; Sharpe, A. G. Inorganic chemistry, $3^{\text {rd }}$ edition, Pearson, 2008, p. 733.

[21] Petrucci, R. General chemistry. Principles and modern applications, McMillan Publishing Company, New York, 1989, 1042. 
[22] Chambers, C.A.; Holliday, K. Modern inorganic chemistry, Butterwoth\&Co, Great Britain, 1975, p. 405.

[23] Drozdov, A.A.; Zlomanov, V. P.; Mazo, G. M.; Spiridonov, F. M. Inorganic chemistry, Vol. 3, book 2, (In Russian), Academy, Moscow, 2004, p. 399.

[24] Lidin, P. A.; Molochko, V. A.; Andreyeva, L. L. Chemical properties of inorganic compounds (In Russian), Khimiya, Moscow, 2000, p. 286.

[25] Tromans, D.; Ahmed, T. Active/Passive Behavior of Copper in Strong Sulfuric Acid. J. Electrochem. Soc., 1998, 145920, $601-608$.
[26] Kiss, L., Kinetics of Electrochemical Metal Dissolution, Budapest: Akademiai Kiado, 1988.

[27] Moreira, A.H.; Benedetti, H. V.; Cabot, P.L.; Sumodjo, P.T.A. Electrochemical behaviour of copper electrode in concentrated sulfuric acid solutions. Electrochim. Acta. 1993, 38(7), 981-987.

[28] Tretyakov, Ju. D.; Martinenko, L. I.; Grigoryev, A. N.; Chivadze, A. Yu. Inorganic chemistry. Chemistry of elements, Vol. 2 (In Russian), MGU, Moscow, 2007, p. 670.

[29] Grishina, E. P.; Udalova, A. M.; Rumyantsev, E. M. Anodic oxidation of copper in concentrated sulfuric acid solutions. Russian Journal of Electrochemistry. 2002, 38(9), 1041-1044.

[30] Zumdal, S. S. Chemistry, $3^{\text {rd }}$ edition; Heath and company, 1993.

\section{Supplementary Material}

\section{Visual materials of students' experiments}

\section{Detection of ions $\mathrm{Cu}^{2+}(\mathrm{aq})$ in solution}

Since solution obtained by dissolving copper in concentrated acid is strongly acidic, a small portion of it is diluted with distilled water until $\mathrm{pH}=5-6$. Addition of $\mathrm{K}_{4}\left[\mathrm{Fe}(\mathrm{CN})_{6}\right](\mathrm{aq})$ to the dilute slightly acidic solution causes precipitation of red-brown sediments:

$$
\left.\left.2 \mathrm{Cu}^{2+}(\mathrm{aq})+\left[\mathrm{Fe}(\mathrm{CN})_{6}\right]^{4-}\right) \mathrm{aq}\right) \rightarrow \underset{\text { brown-red }}{\mathrm{Cu}_{2}\left[\mathrm{Fe}(\mathrm{CN})_{6}\right](\mathrm{s})}
$$

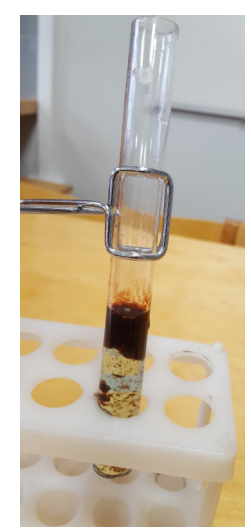

\section{Detection of $\mathrm{SO}_{2}(\mathrm{~g})$}

Into two test tubes aqueous solutions are poured: into first $-1 \% \mathrm{Ca}(\mathrm{OH})_{2}(\mathrm{aq})$, into second $-\mathrm{KMnO}_{4}(\mathrm{aq})$.

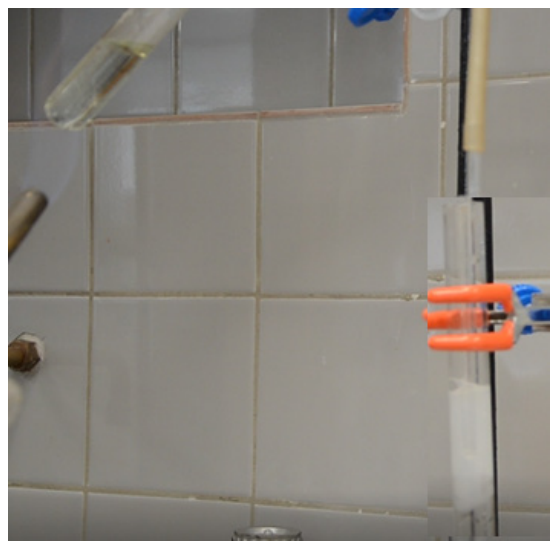

When white gas of a pungent smell is passed through an aqueous solution of $1 \% \mathrm{Ca}(\mathrm{OH})_{2}(\mathrm{aq})$, white sediments precipitate:

$$
\mathrm{SO}_{2}(\mathrm{~g})+\mathrm{Ca}(\mathrm{OH})_{2}(\mathrm{aq}) \rightarrow \underset{\text { white }}{\mathrm{CaSO}_{3}(\mathrm{~s})}+\mathrm{H}_{2} \mathrm{O}(\mathrm{l})
$$

When white gas of a pungent odor is passed through an aqueous solution of $\mathrm{KMnO}_{4}(\mathrm{aq})$, the crimson color of the solution disappears. 


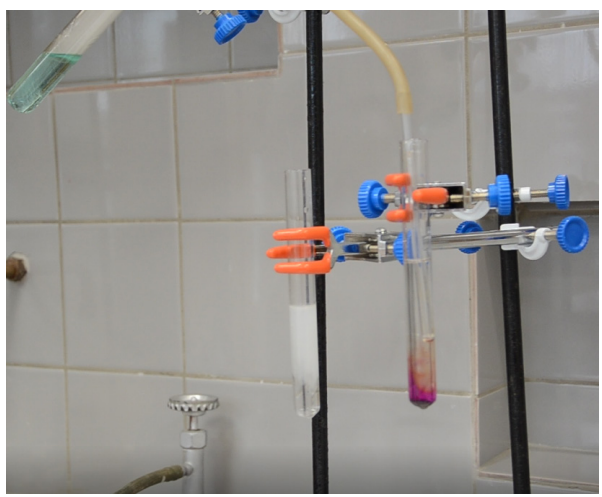

\section{Detection composition of black deposits}

To avoid the influence of ions $\mathrm{SO}_{4}{ }^{2-}$, the black deposit on the surface of copper plate or wire is thoroughly washed with distilled water and kept in distilled water for 6 hours. It is hypothesized that the black deposit consists of copper sulfides $\left(\mathrm{Cu}_{2} \mathrm{~S}\right.$ and $\left.\mathrm{CuS}\right)$ and/or $\mathrm{CuO}$. However, it has been observed that $\mathrm{CuO}$ powder dissolves in dilute sulphuric acid:

$$
\mathrm{CuO}(\mathrm{s})+\mathrm{H}_{2} \mathrm{SO}_{4}(\mathrm{aq}) \stackrel{\Delta}{\longrightarrow} \mathrm{CuSO}_{4}(\mathrm{aq})+\mathrm{H}_{2} \mathrm{O}(\mathrm{l})
$$

Since the black deposit on copper does not dissolve in concentrated sulphuric acid and hydrochloric acid, it is supposed that the black precipitate consists of copper sulphides $\left(\mathrm{Cu}_{2} \mathrm{~S}\right.$ and $\left.\mathrm{CuS}\right)$. When copper sulphides dissolve in nitric acid, $\mathrm{S}^{2-}$ and $\mathrm{Cu}^{+}$ions can act as reducing agents:

$$
\begin{aligned}
& \mathrm{Cu}_{2} \mathrm{~S}(\mathrm{~s})+12 \mathrm{HNO}_{3}(\mathrm{l}) \rightarrow \mathrm{CuSO}_{4}(\mathrm{aq})+\mathrm{Cu}\left(\mathrm{NO}_{3}\right)_{2}(\mathrm{aq})+10 \mathrm{NO}_{2}(\mathrm{~g})+6 \mathrm{H}_{2} \mathrm{O}(\mathrm{l}) \\
& \mathrm{CuS}(\mathrm{s})+8 \mathrm{HNO}_{3}(\mathrm{l}) \rightarrow \mathrm{CuSO}_{4}(\mathrm{aq})+8 \mathrm{NO}_{2}(\mathrm{~g})+4 \mathrm{H}_{2} \mathrm{O}(\mathrm{l})
\end{aligned}
$$

The dissolution of the black deposit and copper in concentrated nitric acid: during the first 20 seconds, black deposit on copper dissolves in nitric acid and $\mathrm{NO}_{2}$ gas evolution is insignificant. After 20 seconds, intensive $\mathrm{NO}_{2}$ gas evolution is observed because copper starts to dissolve: $\mathrm{NO}_{2}$ fills the test-tube with red-brown colour. The colourless liquid becomes green due to formation of complexes of hydrated copper(II) ions with nitrate ions:

$$
\mathrm{Cu}(\mathrm{s})+4 \mathrm{H}^{+}(\mathrm{aq})+4 \mathrm{NO}_{3}{ }^{-}(\mathrm{aq})+2 \mathrm{H}_{2} \mathrm{O}(\mathrm{l}) \rightarrow \underset{\text { green }}{\left[\mathrm{Cu}\left(\mathrm{H}_{2} \mathrm{O}\right)_{4}\left(\mathrm{NO}_{3}\right)_{2}\right](\mathrm{aq})+2 \mathrm{NO}_{2}(\mathrm{~g})}
$$

After dissolution of the black precipitate and copper in concentrated nitric acid, the solution is diluted with distilled water. Concentration of nitrate ions becomes much lower after dilution, and green nitrate complexes of copper(II) are converted to blue $\left[\mathrm{Cu}\left(\mathrm{H}_{2} \mathrm{O}\right)_{6}\right]^{2+}$ :

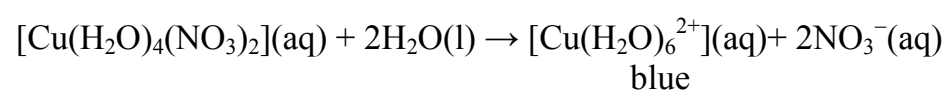

$\mathrm{BaCl}_{2}(\mathrm{aq})$ is used for detection of sulfate ions $\mathrm{SO}_{4}{ }^{2-}$.

$$
\mathrm{CuSO}_{4}(\mathrm{aq})+\mathrm{BaCl}_{2}(\mathrm{aq}) \rightarrow \mathrm{CuCl}_{2}(\mathrm{aq})+\underset{\text { white }}{\mathrm{BaSO}_{4}(\mathrm{~s})}
$$

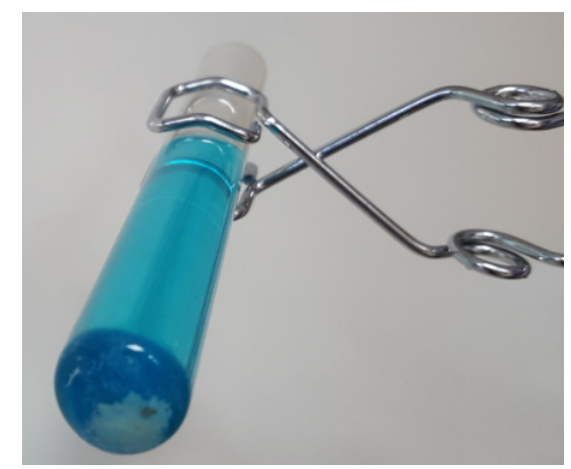

(C) The Author(s) 2019. This article is an open access article distributed under the terms and conditions of the Creative Commons Attribution (CC BY) license (http://creativecommons.org/licenses/by/4.0/). 